\title{
Autopsia del cadáver del excelentísimo señor Libertador General Simón Bolívar
}

El 17 de Diciembre de 1830, a las cuatro de la tarde, en presencia de los señores generales beneméritos Mariano Montilla y José Laurencio Silva, habiéndose hecho la inspección del cadáver en una de las salas de habitación de San Pedro, en donde falleció S.E. el General Bolívar, ofreció las características siguientes:

1ํ HABITUD DEL CUERPO.- Cadáver a los dos tercios de marasmo, descolorimiento universal, tumefacción en la región del sacro, músculos muy poco descoloridos, consistencia natural.

2 CABEZA.- Los vasos de la arachnoides en su mitad posterior ligeramente inyectados, las desigualdades y circunvoluciones del cerebro recubiertas por una materia parduzca de consistencia y transparencia gelatinosa, un poco de serosidad semiroja bajo la dura-máter; el resto del cerebro y cerebelo no ofrecieron en su substancia ningún signo patológico.

3 PECHO.- De los dos lados posterior y superior estaban adheridas las pleuras pulmonares a las pleuras costales por producciones semimembranosas; endurecimiento en los dos tercios superiores de cada pulmón; el derecho casi desorganizado presentó un manantial abierto de color de las heces del vino, jaspeado de algunos tubérculos de diferentes tamaños, no muy blandos; el izquierdo, aunque menos desorganizado, ofreció la misma afección tuberculosa, y dividiéndolo con el escalpelo se descubrió una concreción calcárea irregularmente angulosa de tamaño de una pequeña avellana (1). Abierto el resto de los pulmones con el instrumento, derramó un moco pardusco que por la presión se hizo espumoso. El corazón no ofreció nada particular, aunque bañado de un líquido ligeramente verdoso, contenido en el pericardio.

4 ABDOMEN.- El estómago, dilatado por un licor amarillento de que estaban fuertemente impregnadas sus paredes, no presentó sin embargo ninguna lesión ni flogosis; los intestinos delgados estaban ligeramente meteorizados; la vejiga enteramente vacía y pegada bajo el pubis, no ofreció ningún carácter patológico. El hígado de un volumen considerable, estaba un poco escoriado en su superficie convexa; la vejiga de hiel muy extendida; las glándulas mesentéricas obstruidas; el bazo y los riñones en buen estado. Las vísceras del abdomen en general no sufrían lesiones graves.

Según este examen es fácil reconocer que la enfermedad de que ha muerto S. E. el Libertador era en su principio un catarro pulmonar, que habiendo sido descuidado pasó al estado crónico y consecutivamente degeneró en tisis tuberculosa. Fue pues esta afección morbílica la que condujo al sepulcro al General Bolívar, pues no deben considerarse sino como causas secundarias las diferentes complicaciones que sobrevinieron en los últimas días de su enfermedad, tales como la arachnoides y la neurosis de la digestión, cuyo signo principal era un hipo casi continuo; y ¿quién no sabe por otra parte que casi siempre se encuentra alguna irritación local extraña al pecho en la tisis con degeneración del parenchima pulmonar? Si se atiende a la rapidez de la enfermedad en su marcha y los signos patológicos informados sobre el órgano de la respiración, naturalmente es de creerse que causas particulares influyeron en los progresos de esta afección. No hay duda que agentes físicos ocasionaron primitivamente el catarro del pulmón, tanto más cuanto que la constitución individual favorecía el desarrollo de esta enfermedad que la falta de cuidado hizo más grave; que el viaje por mar

(1) La cual existe en poder del médico de cabecera. 
que emprendió el Libertador con el fin de mejorar su salud, le condujo al contrario a un estado de consunción deplorable, no se puede contestar; pero también debe confesarse que afecciones morales vivas y punzantes como debían ser las que afligían continuamente el alma del General, contribuyeron poderosamente a imprimir en la enfermedad un carácter de rapidez y en su desarrollo, y de gravedad en las complicaciones, que hicieron infructuosos los socorros del arte.

Debe observarse en favor de esta serción, que el Libertador, cuando el mal estaba en su principio, se mostró muy indiferente a su estado, y se denegó a admitir los cuidados de un médico; S.E. mismo lo ha confesado; era cabalmente en el tiempo en que sus enemigos lo hartaban de disgustos, y en el que estaba más expuesto a los ultrajes de aquellos que sus beneficios habían hecho ingratos. Cuando S.E. llegó a Santa Marta, bajo auspicios mucho más favorables, con la esperanza de un porvenir más dichoso para la patria, de quien veía brillantes defensores entre los que le rodeaban, la naturaleza conservadora retornó sus derechos; entonces pidió con ansias los socorros de la medicina. Pero ¡ha! Ya no era tiempo! El sepulcro estaba abierto aguardando la ilustre víctima, y hubiera sido necesario hacer un milagro para impedirle descender a él.-

San Pedro, Diciembre 17 de 1830, a las ocho de la noche.-

Alejandro Próspero Reverend 